\title{
ONLINE TICKETING AND CUSTOMER SATISFACTION ANALYSIS: AN EXPLORATORY RESEARCH CONCERNING CUSTOMERS IN THE CONTEXT OF BURKINA FASO.
}

\author{
Nathalie Kiswendsida Zongo ${ }^{1,5}$, Dr. Théophile Bindeouè Nasse $e^{2,3,4,6,7}$ \\ ${ }^{1}$ Amity University, Uttar Pradesh (India) \\ ${ }^{2}$ New Dawn University (Burkina Faso) \\ ${ }^{3}$ University for Development Studies (Ghana) \\ ${ }^{4}$ University Ouaga 2 (Burkina Faso) \\ ${ }^{5}$ University of Ouagadougou (Burkina Faso) \\ ${ }^{6}$ Polytechnic College of Youth (Burkina Faso) \\ ${ }^{7}$ Saint Thomas D'Aquin University (Burkina Faso)
}

*Corresponding Author: Dr. Théophile Bindeouè Nassè.
Corresponding Author Email: nassetheophile2009@ gmail.com

Article Received: 05-05-19

Accepted: 03-07-19
Published: 18-07-19

Licensing Details: Author retains the right of this article. The article is distributed under the terms of the Creative Commons Attribution-Non Commercial 4.0 License (http://www.creativecommons.org/licences/by-nc/4.0/) which permits non-commercial use, reproduction and distribution of the work without further permission provided the original work is attributed as specified on the Journal open access page.

\section{ABSTRACT}

Most studies on revenue or yield management have focused on its benefits to airline companies (Anderson \& Wilson, 2003; Jerath, Netessine \& Veeraraghavan, 2010). Then, the buying behavior of airline passengers has been studied by Diggines (2010), Gupta, Su and Walter (2004) and Yu (2008). General customer search theory has explored the strategies that customers use to make a purchase decision (Stigler, 1961; Koch \& Cebula, 2002; Öörni, 2003; Armstrong, Vickers \& Zhou 2009). The airline industry has known some difficulties as the overall world economy. Therefore, the challenge of each airline company is to cut costs while increasing profitability and achieving a satisfactory customer service. For this research, the approach is a quantitative one; a stratified random sampling is used and 131 completed questionnaires are collected for the subsequent analysis. The statistical software sphinx IQ is used to analyze the data. Four (4) dimensions of e-service quality are identified, i.e. website ease of use, website design, website reliability and responsiveness. The results show that these four (4) dimensions have an effect on customer satisfaction.

Keywords: Customer, Satisfaction, Online, Ticketing, Burkina Faso, Marketing. 


\section{INTRODUCTION}

First of all, the airline industry is publicly seen and accepted as the fastest and safest way of travel. For Heung (2003) online ticketing is one of the best ways of purchasing tickets by airline customers. However, the management of the customer relationship in the context of Africa and particularly in the context of Burkina Faso is still facing some daily challenges (Nasse, 2019). For further, in the airline industry, durability is a much valuable strength. Then, the ability of an airline company to pursue its operations in duration makes it reliable. Formerly, internet was used as a channel of communication by airlines as in other industries. Airline companies' websites were serving only marketing and sales promotion. Today, airline companies now understand that internet is a unique opportunity for them to reach existing and potential customers. Thus, they are exploiting the tremendous potential of internet to conduct satisfaction surveys with customers and also for online ticketing. From this perspective, airline companies operating from Burkina Faso, have been engaged in this process of online ticketing for several years. Online ticketing is an opportunity, to enhance customer service and to reach profitability. The airline industry is a very competitive and costly business environment, and this situation drives airline companies to develop solutions to take cost advantage and make profit. Thus, analyzing and identifying factors that influence customer satisfaction is vital. Customers' demands are always changing. Therefore, answering to customers' demands may then help retaining them. The interest of this research is focused on factors such as usage of the internet for online ticketing, the components leading to satisfaction and then impact purchase intention therefore increase retention. Practically, the study is conducted among people who purchase and use flight tickets. It encompasses online shopping behavior literature, online shopping, and electronic commerce dimensions. Some previous studies on customer satisfaction have been made in the area of small and medium sized companies in the context of Burkina Faso (Nasse, 2019) and the results have shown that the customer satisfaction is driven by the price and the quality of services or products. The present research aims to check customer satisfaction in regard of services offered in the area of online ticketing and in a big company context. The online ticketing offered to customers in the area of airline is very challenging. Therefore it is common to find some customers that are complaining about the quality of the online ticketing. This brought, the present researchers to have the following question in mind: What are the factors that can influence online ticketing customer satisfaction?

This research is an exploratory one that is conducted in the airline sector in the context of Burkina Faso and it seeks to understand customer's perception, in order to stimulate online ticketing, to increase online sales revenue and then, to contribute in reducing distribution costs. This will impact the overall company revenue and contribute to ensure its continued existence. The general objective is to analyze the factors that lead the customers to be satisfied when using online ticketing as a solution and how this satisfaction impacts their purchase intention. The specific objectives are four. The first objective is to assess the relationship between website ease and customer satisfaction. The second objective is to examine the relationship between website design and customer satisfaction. The third objective is to examine the relationship between website reliability and customer satisfaction. 
The fourth objective is to evaluate the relationship between responsiveness and customer satisfaction. The following section is about the review of the literature.

\section{LITERATURE REVIEW}

The current literature is mainly focused on the development of online ticketing and his targeted to identifying the key determinants of a service quality in online buying context.

The concept of online ticketing : In today Business world, worldwide customers can be reached using the power of internet. Zwass (1996) argues that it is in the 1960s that e-business started after electronic data interchange. However, Melão (2009) suggests that actual revolution occurred after the 1990s, when e-business developed after using the internet. Electronic ticket appeared in the airline industry in 1994 and it has been made mandatory for most of the traditional travel agents, online intermediaries, and airline websites. Heung (2003) argues that E-ticketing is the preferred option for airline customers to purchase their tickets. Koo, Mantin and O'Connor (2009) researches have highlighted the increasing migration of customers towards purchasing online.

The concept of customer satisfaction : According to Nasse, (2019), higher service quality is required in order to obtain customer satisfaction as it can be considered as a predictor of customer satisfaction. Nasse (2019) shows that in the Burkinabe context for a given customer to be satisfied the company must provide some products or services that meet the expectations of the customer in term of quality as compared to the price. Thus, the quality of a product or a service may bring a customer satisfaction or dissatisfaction. That is what the model of Nasse (2019) shows:

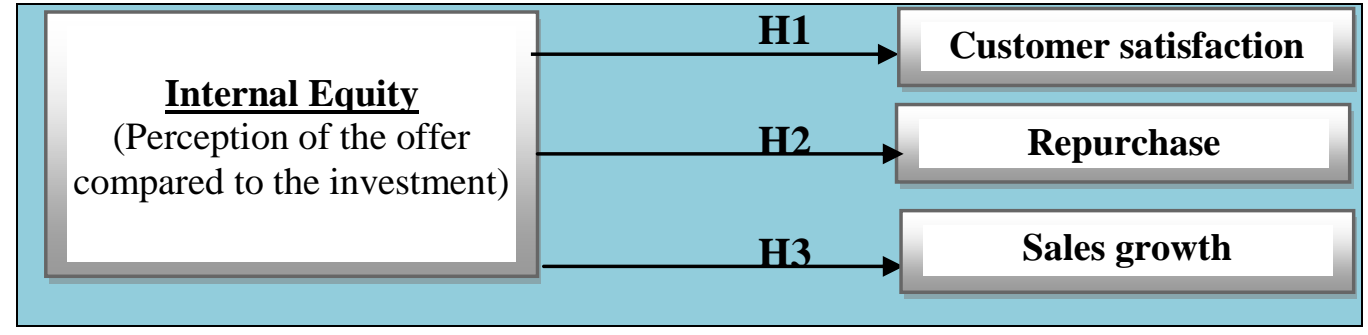

Figure 1 : Research model (Nasse, 2019)

For Kotler and Armstrong (2010), customer satisfaction is related to the product's perceived performance relative to a buyer's expectations and then leads to loyalty. Then, assuring a top internet service quality is vital for e-Business. Parasuraman, Zeithaml and Berry (1988) go that service quality is the customers' judgment about the overall excellence of a service provider. If a customer perceives a greater service quality as compared to his/her expectations, he/she will be highly satisfied with his/her purchase. Whereas, if a customer experiences lower service quality as compared to the expected quality, so his/her customer satisfaction will decline. According to the service quality model, there are five dimensions including empathy, assurance, responsiveness, reliability and tangibility.

The concept of purchase intention: For authors like Van Laethem and Body (2008), Kitchathorn (2009), Nasse (2019), Nasse and Sawadogo (2019) purchase intention refers to the will of the customer to buy the products of a given company and the process could be 
renewed due to satisfaction. According to Kotler and Armstrong (2010), customer satisfaction is related to the product's perceived performance relative to a buyer's expectations. For any organization, customer satisfaction plays important role in creating satisfied customers who can come back to repurchase products. Nowadays, more organizations are realizing that it is less expensive to retain existing customer than attracting new customers.

The concept of ease of use: Perceived ease of use for online purchasing refers to the degree to which the prospective customer expects the online purchases to be free of effort. Teo (2011) suggests that perceived ease of use is important for using internet products such as purchasing, downloading, browsing, and messaging. Perceived ease of use of website is likely to increase its user's satisfaction because it is perceived performing. Hoffman and Novak (1996) argue that the ease of use of a website increases its user sensation of control over the website.

The concept of website design: Website design is related to the site creativity with multimedia and color graphics. Besides, website design is how friendly customers feel the website when using an online store services (Parasuraman \& al., 1988). Zeithaml et al. (2000). Madu and Madu (2002) underline that a well design website that is easy to use is the starting point to enhance users' confidence. For Wolfinbarger and Gilly (2000), and Wolfinbarger and Gilly (2001), design is an important factor in determining how customers judge the website quality.

The concept of reliability: Reliability is the dimension in which parties that are engaged in a business can trust each other. Then, it implies uncertainty, vulnerability and dependence. Reliability also refers to security and privacy. These dimensions are likely true in the online service context as the customer and the seller are not in a face-to face transaction. The expectation of the customer to getting the right delivery is based on belief in the merchant's technical competence, goodwill and past experience with the online retailer. Lim and Dubinsky (2004) state that some websites sometimes required much personal information from their customers when purchasing, then making them feel uncomfortable. Moreover, assurance refers to customers' perceived security and privacy when using e-retailing services (Ribbink \& al., 2004). For Zeithaml et al. (2000), security is one of the primary barriers to online shopping and it is an important factor that affects e-satisfaction. Nasse (2016) shows that in the Burkinabe context for a given customer to be satisfied the company must provide some fair products, fair prices and some fair practices and avoid the unfair practices, thus, showing that when a company wants to get some profits it must be reliable in the perception of its customers.

The concept of responsiveness: Responsiveness is related to the amount that the online service provider is prepared to deliver the service. It is about keeping c' -ustomers informed about when the service will be performed. Responsiveness is all related to a prompt service to customers, willingness to help customers and readiness to respond to customers' request. Yang and Jun (2002) state that responsiveness is considered important for both overall service quality and satisfaction. Still, Nasse (2016) shows that in the Burkinabe context for customer to be satisfied the company must meet the expectations of its customers in term of products price as compared to the quality of the product or the service provided; Nasse also emphasizes 
that the company reactivity to a given customer's needs and expectations has to be fast. After, defining the concepts, the different theories in line with the research are also brought out.

The theory of equity in business: Homans (1961), Adams (1963), Zeithaml et al. (2004), Peretti (2004), Aravindakshan et al. (2004), Morrisson (2005), and Nasse (2019), highlight the notion of equity resulting from the comparison of what an individual perceives in an exchange "output, profit" and the "input, investment " S/he brings. They demonstrate that equity not only influences customer satisfaction but also, equity influences customer repurchases. They show that equity is important for any business.

\section{RESEARCH METHODOLOGY.}

The research is conducted by presenting the methodology. It also discusses the research design.

Research design : The exploratory method has been used at the early stages of this research. The purpose of this exploratory method is to understand the research topic and how to lead the research. Furthermore, quantitative method has been used to collect data related to the topic. This quantitative method consisted of using internet self-administered questionnaire and on board paper administered questionnaire to collect the data.

Determination of information needs and sources: Information is a collection of data used to achieve a specific purpose. Several protocols exist for information: random interview, selected sample interview (via e-mail or face-to-face), observation, questionnaires, etc. Paisly and Mick (1972) use the concept of multiple operationalism to state that each methodology has a unique set of error factors including test bias, sampling bias and response problems in questionnaire and interview formats. For the purpose of this research, usage of internet, books, reviews, reports and questionnaire are made.

Primary data: There are many different methods in collecting data such as traditional mail, face to face, telephone, electronic mail and the combination of these methods (Cooper \& Schindler, 2001; Sekaran, 2000). The primary data for this research are collected through a structured questionnaire to answer the research questions and objectives. The survey questionnaire consists of ten questions related to four distinct sections pertaining to different parts of the study. The survey questionnaires are administered using stratified random sampling method to reach 200 people who purchase and use airline tickets. Two ways of administration are used. First, a self-administered questionnaire sent by E-mail from the online customers' e-mail addresses data base. Second, a paper based questionnaire administered on board on the air flights of a big company. The research is conducted from $1^{\text {st }}$ May, 2016 to the $30^{\text {th }}$ June, 2016. Online administration has the advantage to be easily distributed. The questionnaire is sent to the respondents' Email and the respondents respond via a returned E-mail. Leelayouthayotin (2004) underline that advantages of self-administered questionnaire are as lower cost, easy to administered and fast delivery, reach wider coverage and respondents can answer at their convenience. Unfortunately, this kind of administration has also some limits such as low response rates. An advantage of paper based administration is the high rate of questionnaires recovery. One of the limitations is that the respondent has a given time to respond to the questionnaire. 
Sample size: Sampling is one component of a research design (Malhotra \& Birks, 2000). The sample is a representative part in a target population. The target population of this research refers to the customers who purchase and use air tickets. Fisher (2007) states that the size of a sample depends on the size of the margin error the researcher can accept and the size of the total population. For this research, the sample consists of 200 people. The sampling strategy comprises a stratified random sampling technique due to a lack of time. The sample size is determined by using the following formula: $\mathrm{N}=(\mathrm{p})(1-\mathrm{p}) /(\mathrm{e} / \mathrm{Z})^{2} ; \mathrm{p}$ represents the selected proportion of an attribute. Assuming a 50-50 female to male ratio, $\mathrm{p}=0.50$ or $50 \%$; e represents the level of precision, here $9 \%$, and $\mathrm{Z}$ is the number related to the degree of confidence $Z=1.96$ (Ganassali, 2009; Hejase and Hejase, 2013). The number of people to interview for a maximum error of $9.0 \%$ is $\mathrm{N}=0.25 /(0.09 / 1.96)^{2}=118$ people. A sample of 131 respondents is enough for a 9 point error estimate. Once the sample determined, data collection is done through a questionnaire on a paper and it is filled by the customers. The total number of respondents is 131 .

Questionnaire design: According to Fisher (2007) several issues must be taken into account when designing a questionnaire. The questionnaire should be relatively short, concise, and definitely, it should look attractive. For this research, a questionnaire of 10 questions was designed. Demographic questions are asked to respondents in the first part of the questionnaire, including the class of travel, gender and age. The questions are distributed to individuals who have at least one online ticketing experience. Therefore, the respondents are asked to respond to the ten questions related to the research variables which are: Ease of use, website design, reliability and responsiveness. A total of 131 usable questionnaires are collected and they are analyzed.

Ethical considerations: The present research is restricted because of some ethical purposes, and this is typical to the West African context where companies also protect their data (Nasse, 2016).

\section{Research model and research hypotheses.}

Based on the studies of previous research, relevant hypotheses are developed. These hypotheses are:

$\mathrm{H}_{1:}$ Ease of use positively influences customer satisfaction;

$\mathrm{H}_{2}$ : Website design positively influences customer satisfaction;

$\mathrm{H}_{3}$ : Reliability positively influences customer satisfaction;

$\mathrm{H}_{4}$ : Responsiveness positively influences customer satisfaction.

From the above hypotheses, a research model is designed (See the following figure 2) 


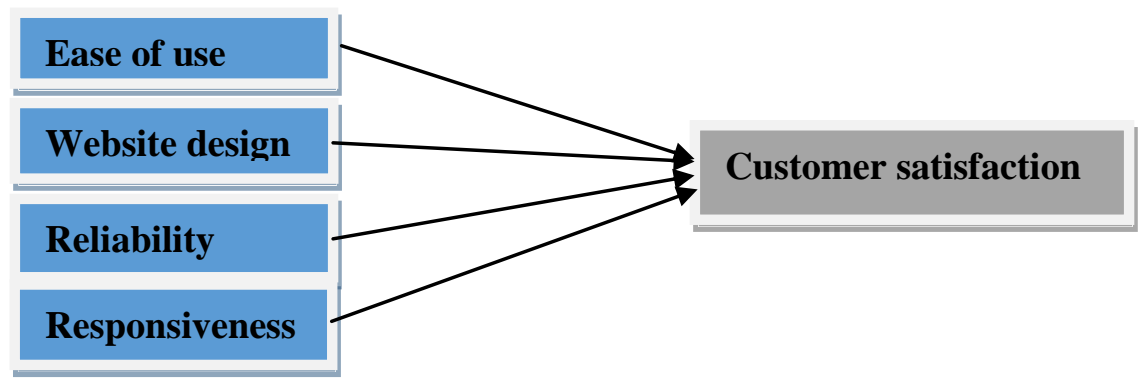

Figure 2: Research model (Source, Zongo, 2016)

\section{RESEARCH RESULTS}

The travel class of respondents is summarized in table 1. Two cabins of travel class exist on the air flights (Business cabin and Economy cabin). Most of the respondents are travelling in Economy class $(81.70 \%)$ versus $18.30 \%$ travelling in Business class.

Table 1

Travel class (Personal source, 2016)

\begin{tabular}{lcc}
\hline Travel class & Respondents' number & Percentage \\
\hline Business cabin & 24 & $18.30 \%$ \\
\hline Economy cabin & 107 & $81.70 \%)$ \\
\hline
\end{tabular}

The respondents' ages are summarized on the following table 2. Four categories are used gathering information about the age of the respondents. The respondents aged between 41 to 60 years are $52.7 \%$, and then, those who are aged between 20 to 40 years old represent $44.3 \%$ ), and then those who are over 60 years are $2.3 \%$ and finally those under 20 years are $0.8 \%$.

Table 2

Age of respondents (Personal source, 2016)

\begin{tabular}{lcc}
\hline Age range & Respondents' number & Percentage \\
\hline 12 to 19 years old & 1 & $0.8 \%$ \\
\hline 20 to 40 years old & 58 & $44.3 \%$ \\
\hline 41 to 60 years old & 69 & $52.7 \%$ \\
\hline More than 60 years old & 3 & $2.3 \%$ \\
\hline
\end{tabular}

Table 3 shows the gender of the respondents. $76.3 \%$ of the respondents are men and $33.7 \%$ of the respondents are women.

Table 3

Gender of the respondents (Personal source, 2016).

\begin{tabular}{lcc}
\hline Gender & Respondents' number & $\frac{\text { Percentage }}{76.30 \%}$ \\
\hline Men & 87 & $33.70 \%)$ \\
\hline Women & 44 & \\
\hline
\end{tabular}

Table 4 shows the website access easiness according to the respondents. The first item in questionnaire related to website is the easiness of access. $86.3 \%$ find that the website is easy to access, and $13.7 \%$ of the respondents find that the website is not easy to access.

Table 4

Website access easiness (Personal source, 2016)

\begin{tabular}{lcc}
\hline Website access easiness & Respondents' number & Percentage \\
\hline The website is not easy to access & 113 & $86.30 \%$ \\
\hline The website is easy to access & 18 & $13.70 \%)$ \\
\hline
\end{tabular}


Table 5 shows the website attractiveness according to the respondents. $77.9 \%$ find that the website is attractive, and $22.10 \%$ do not find the website attractive.

Table 5

Website attractiveness (Personal source, 2016).

\begin{tabular}{|c|c|c|}
\hline Website attractiveness & Respondents' number & Percentage \\
\hline The website is attractive & 102 & $77.90 \%$ \\
\hline The website is not attractive & 29 & $22.10 \%)$ \\
\hline
\end{tabular}

Table 6 shows the booking engine transaction's quickness and easiness. $65.6 \%$ find that it is quick and easy to complete transactions on the booking engine. In the opposite, $34.4 \%$ find that it is not quick and easy to complete transactions on the booking engine.

Table 6

Booking engine transaction's quickness and easiness (Personal source, 2016).

Booking engine transaction's quickness and easiness Respondents' number $\quad$ Percentage

$\begin{array}{llll}\text { The booking engine transaction is quick and easy } & 86 & 65.60 \%\end{array}$

$\begin{array}{lll}\text { The booking engine transaction is not quick and easy } & 45 & 34.40 \%)\end{array}$

Table 7 shows the website design clarity according to the respondents' answers on the website design clarity. For $81.70 \%$ of the respondents, the website design is clear while for $18.30 \%$ the website design is not clear.

Table 7

Website design clarity (Personal source, 2016)

\begin{tabular}{lc}
\hline Website design clarity & Percentage \\
\hline The website design is clear & $81.70 \%$ \\
\hline The website design is not clear & $18.30 \%)$
\end{tabular}

Table 8 shows the website reliability. Regarding Security and privacy of the website, $77.1 \%$ think that security and privacy are guaranteed. $22.9 \%$ think that security and privacy are not guaranteed.

Table 8

Website reliability (Personal source, 2016).

\begin{tabular}{lc}
\hline Website reliability & $\underline{\text { Percentage }}$ \\
\hline The website is reliable & $77.10 \%$ \\
\hline The website is not reliable & $22.90 \%)$ \\
\hline
\end{tabular}

Table 9 shows the website responsiveness. Respondents are asked about the responsiveness, mainly if the E-mails responses sent are relevant and accurate to customers. $75.60 \%$ find that the E-mails are relevant and accurate, and $24.40 \%$ find that the E-mails are not relevant and accurate.

Table 9

Website responsiveness (Personal source, 2016).

\begin{tabular}{ll}
\hline Website responsiveness & Percentage \\
\hline E-mails responses are relevant and accurate & $75.60 \%$ \\
\hline E-mails responses are not relevant and accurate & $24.40 \%)$ \\
\hline
\end{tabular}


Table 10 shows customer satisfaction. The last item is related to customer overall satisfaction on the online ticketing. $84.7 \%$ of the respondents say that they are satisfied of the online ticketing, and $15.3 \%$ of the respondents say that they are not satisfied of the online ticketing.

Table 10

Customer satisfaction (Personal source, 2016).

\begin{tabular}{ll}
\hline Customer satisfaction & Percentage \\
\hline Satisfied & $84.70 \%$ \\
\hline Non satisfied & $15.30 \%)$ \\
\hline
\end{tabular}

In addition, to that 'customer satisfaction' variable is crossed with other variables to see if the relationships are significant.

Table 11

Crossing of the different variables (Personal source, 2016)

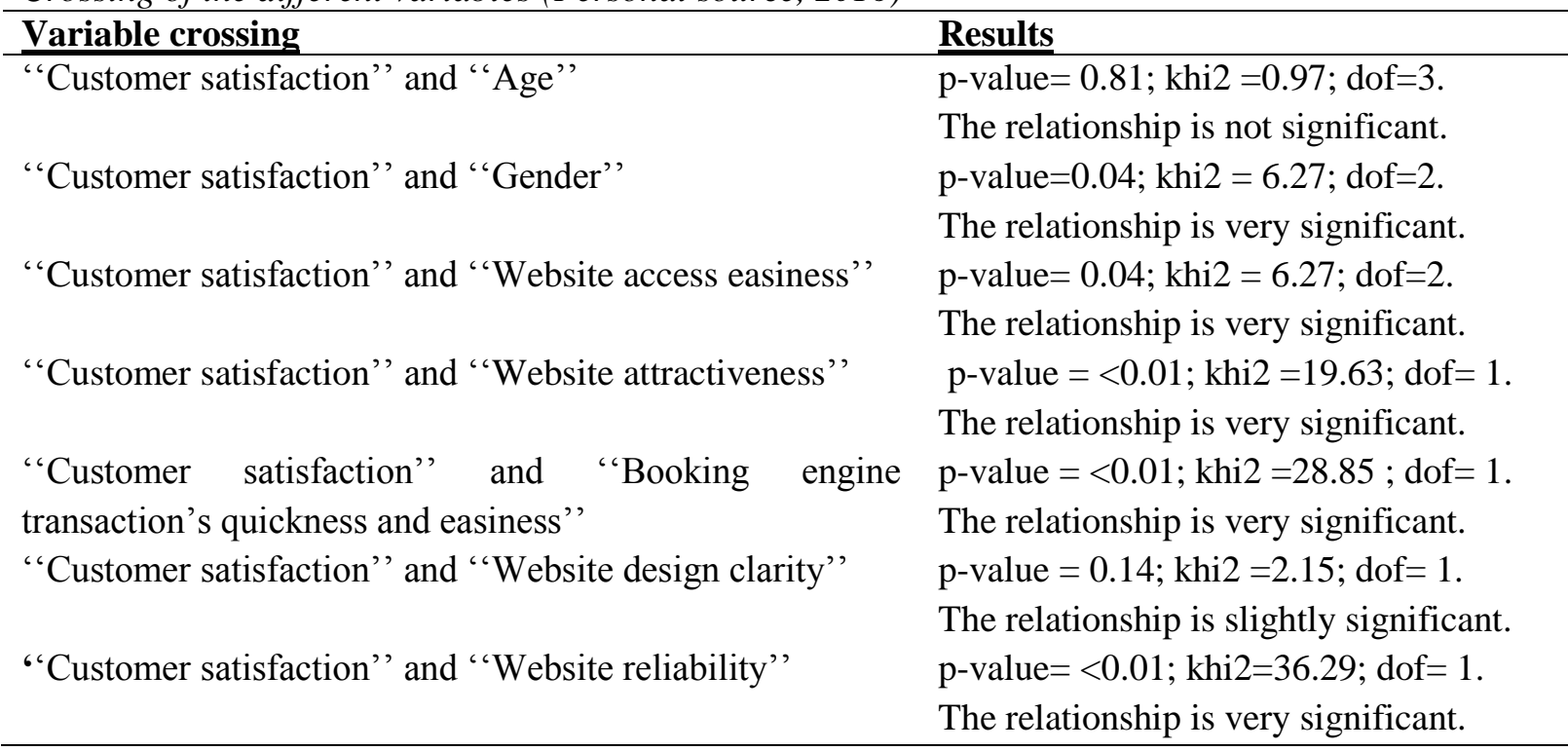

The crossing of customer satisfaction and age gives a $\mathrm{p}$-value $=0.81$; a chi-square $=0.97$; and a degree of freedom $(\mathrm{dof})=3$. Therefore, there is not a relationship between customer satisfaction and age (see the above table 11). In addition, the crossing of customer satisfaction and gender gives a $\mathrm{p}$-value $=0.04$; a chi-square $=6.27$ and a degree of freedom $(\mathrm{dof})=2$. Then, there is a strong relationship between customer satisfaction and gender (see table 11). For further, the crossing of customer satisfaction and website access easiness gives a $p$-value $=<0.01$; a chi-square $=26.18$ and a degree of freedom $(\operatorname{dof})=1$. As a consequence, there is a very strong relationship between customer satisfaction and website access easiness (see the above table 11). Moreover, the crossing of customer satisfaction and website attractiveness gives a $p$-value $=<0.01$; a chi-square $=19.63$; and a degree of freedom $($ dof $)=$ 1. Therefore there is a very strong relationship between customer satisfaction and website attractiveness (see the above table 11). Furthermore, the crossing of customer satisfaction and booking engine transaction's quickness and easiness gives $\mathrm{p}$-value $=<0.01$; a chi-square khi2 $=28.85$ and a degree of freedom $(\mathrm{dof})=1$. Hence, there is a very strong relationship between 
customer satisfaction and booking engine transaction's quickness and easiness (see table 11). The crossing of customer satisfaction and website design clarity gives a p-value $=0.14$; a chi-square $=2.15$; and a degree of freedom $(\mathrm{dof})=1$. Consequently, there is a relationship between customer satisfaction and website access easiness though this relationship is slightly significant (see table 6). The crossing of customer satisfaction and website reliability gives pvalue $=<0.01 ;$ a chi-square $=36.29$ and a degree of freedom $($ dof $)=1$. Thus, there is a very strong relationship between customer satisfaction and website reliability (see table 11). The crossing of customer satisfaction and responsiveness gives a $p$-value $=<0.01$; a chi-square $=$ 39.49 and a degree of freedom $(\mathrm{dof})=1$. Then, there is a very strong relationship between customer satisfaction and responsiveness (see the above table 11). Still, to check if the relationship between customer satisfaction and the other variables is strong, the different variables are crossed together what gives this graph of relationship between the variables. The results show that the relationship is very strong between customer satisfaction and the other variables.

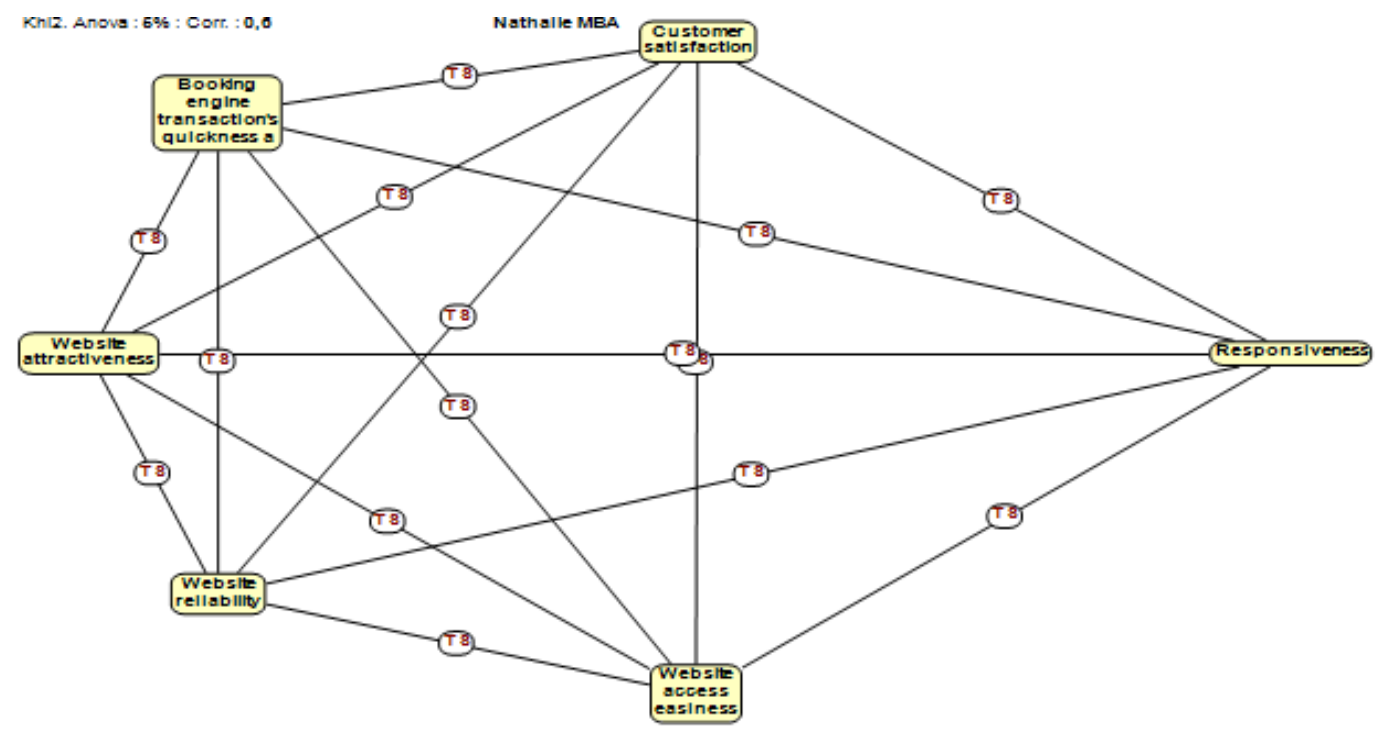

Figure 3: Graph of relationships between variables (Source, data analysis, 2016)

NB: TS is derived from the French Très Significatif what means Very Significative in English.

\section{DISCUSSION OF THE RESULTS}

There are four dimensions addressed in this research: website Ease of use, website design, website reliability and website responsiveness. The main purpose of this research is to find out the relationship between each of these dimensions and customer satisfaction. Customer often has the opinion of the quality of products or services on the basis of a variety of informational cues that they associate with the products or services (Schiffman, 2000). The analytical results show that the dimensions of website ease of use, design, reliability, responsiveness affect the overall service quality and customer satisfaction. Then, the research hypotheses are supported. The online service quality measure developed in this research is designed to provide an effective tool to assess online ticketing service quality. To enhance 
customer satisfaction when using online ticketing, the website must be easier to use, better designed, more reliable and more responsive. The three dimensions that affect online ticketing customer satisfaction very significantly are 'Ease of use', 'Reliability' and 'Responsiveness'. 'Website design' affects customer satisfaction in regard of online ticketing less significantly. It is important for airline companies to simplify their websites information and configuration. Thus, the results of this research are in line with Ribbink et al. (2004) research. In the context of web-based market, the 'Ease of use' feature is essential to attract both experienced online customers and new online customers. As from the research results, reliability is also known to be an important factor that influences customer satisfaction. It is recommended that airline companies enhance the level of privacy and security since, this variable affects customer satisfaction significantly. Airline companies should integrate some clear defined security policies and privacy policies to insure their customers. The research results also show that responsiveness affects customer satisfaction very significantly. This is consistent with prior studies by Swaid and Wigand (2007) and by Lee and Lin (2005). Airlines are then recommended to provide an accurate and a prompt response to customers' needs. Thus, reactivity to respond to customer needs should be quick (Nasse, 2019).

A well-designed navigation structure can facilitate customers' perceptions of online service quality. The website design dimension shows that there is a need to develop user responsive websites which will ease customer navigation.

Table 12

Summary of results in relation to the research hypotheses (Source, data analysis, 2016).

\begin{tabular}{ll}
\hline Research hypotheses & $\underline{\text { Findings }}$ \\
\hline H1 Ease of use positively influences customer satisfaction & Supported \\
H2 Website design positively influences customer satisfaction & Supported \\
H3 Reliability positively influences customer satisfaction & Supported \\
H4 Responsiveness positively influences customer satisfaction & Supported \\
\hline
\end{tabular}

\section{$H_{1}=$ Ease of use positively influences customer satisfaction.}

This variable is related to the extent that the customer perceives a website easy to use making him/her comfortable when purchasing tickets online. Customers are questioned to state if the website is easy to access or not. The majority find that the site is easy to access. The results of the research show a positive relationship between website 'Ease of use' and 'Customer satisfaction'. The p-value and the chi-square analysis show a strong positive relationship between ease of use and customer satisfaction. Then, website ease of use highly contributes to customer satisfaction at the same extent as reliability and responsiveness.

\section{$\mathrm{H}_{2}=$ Website design positively influences customer satisfaction.}

Madu and Madu (2002) underline that a well design website that is easy to use is the starting point to enhance users' confidence. For this research, respondents are questioned to state whether the website design is clear or not. The majority of respondents find the design clear. Further, the relationship analysis shows a weak positive relationship between 'Website sign' 
and 'Customer satisfaction'. Thus, website design in this research is the less significant influencing variable on customer satisfaction.

\section{$\mathrm{H}_{3}=$ Reliability positively influences customer satisfaction .}

Grönroos (1983) finds that reliability is connected to the consistency of performance and dependability. Then, it is fundamental for a company to deliver the promised service. For reliability dimension, customers are asked to state if ever security and privacy are guaranteed on the website. The results of the research are in right line with Grönroos (1983) conclusion. 'Reliability' has a strong positive relationship with 'Customer satisfaction'. Besides, in this research, it contributes to the same extent as ease of use and responsiveness to customer satisfaction.

\section{H4 = Responsiveness positively influences customer satisfaction.}

Grönroos (1983) also finds that responsiveness affects customer satisfaction. This factor shows the extent that the employees are prepared to provide service. This is related to giving prompt and adequate response to the customer needs. In the research, customers are questioned to know whether the E-mail responses sent, consecutively to online ticketing transaction are accurate and relevant. The majority of respondents answered positively and the analysis shows a strong positive relationship between 'responsiveness' and 'customer satisfaction'.

For further, in this research, the results show that responsiveness, ease of use and reliability contribute to an equal extent to customer satisfaction when using online ticketing system.

\section{CONCLUSION AND IMPLICATIONS}

With the competition in the airline sector, today customer's satisfaction is a determinant key element to airline success. Then, airline companies must develop various policies to provide guaranteed qualitative services to customers. The purpose of this research is to investigate airline online ticketing customer's satisfaction in the context of Burkina Faso. The four dimensions of online ticketing studied in this research are found to be significant and they positively influence customer's satisfaction. This research findings show that customers are satisfied to the overall online service. Customers are satisfied about the website ease of use, the website design, the website reliability and the website responsiveness. Customer satisfaction leads to customer's retention while dissatisfaction leads to customer disloyalty (Ranaweera \& Prabhu, 2003; Nasse, 2016; Nasse \& Sawadogo, 2019; Nasse, 2019). Customer satisfaction also contributes to profitability (Anderson, Fornell, \& Lehmann, 1994; Nasse, 2019). For a future research, it will be a question of investigating the same subject in some biggest companies to see if the results will be the same. E-commerce has rapidly grown in the business world, forcing airline companies to compete in online business world. Thus, the knowledge of factors that influence the customer satisfaction when using online ticketing service may allow companies to take an advantage in providing a qualitative e-service. The findings show that the most influencing factors in this research are accessibility, reliability and responsiveness. The findings also suggest that there is a necessity to enhance several e- 
service quality dimensions to ensure high level of customer satisfaction. In a smaller extent, website design has an influence on customer's satisfaction. Marketing managers should periodically survey customers to assess the level of satisfaction.

Limitations and future research: Several limitations in this research are related to the sample of research and the research design. A sample of 200 people purchasing and using air tickets is used with 131 respondents who responded correctly to the questions. This sample might not be representative of the total yearly population that is using the service. Future research should widen the sample in order to make it more representative and find out if price is a factor that will lead to online customer's satisfaction. It should also examine the mediating effects of affective features (trust and empathy) on purchase intention.

\section{References}

Adams, J. S. (1963).Towards an understanding of inequity. Journal of Abnormal and Social Psychology, 1(67), 422-436.

Anderson, C. K., \& Wilson, J. G. (2003). Wait or buy? The strategic consumer: pricing and profit implications. Journal of the Operational Research Society, 54(3), 299-306.

Anderson, E., Fornell, C., \& Lehmann, D. R. (1994). Customer satisfaction, Market share, and Profitability: Findings from Sweden. Journal of Marketing, 58(2), 53-66.

Aravindakshan, A., Rust, R. T., Lemon, K. N., \& Zeithaml, V. A. (2004). Customer equity: making marketing strategy financially accountable. Journal of Systems Science and Systems Engineering, 13(4), 1-15.

Armstrong, M., Vickers, M., \& Zhou, J. (2009). Prominence and consumer search. RAND Journal of Economics, 40(2), 209-233.

Diggines, C. (2010). Passenger perceptions and understanding of the low-cost and full-service airline models in South Africa and the implications for service strategy. International Research Symposium in Service Management, 2(2), 24-27.

Fisher, C. (2007). Researching and Writing a Dissertation- for business students. England, EN: Prentice Hall.

Ganassali, S. (2009). Les enquêtes par questionnaires avec sphinx. Paris, PA: Pearson Education.

Grönroos, C. (1983). Strategic management and marketing in the service sector. Boston, BO: Marketing Science Institute.

Gupta, A., Su, B., \& Walter, Z. (2004). An empirical study of consumers switching from traditional to electronic channels: a purchase-decision process perspective. International Journal of Electronic Commerce, 8(3), 131-161.

Hejase, A. J., \& Hejase, H. J. (2013). Research methods, a practical approach for business students ( $2^{\text {nd }}$ ed.). Philadelphia, $\mathrm{PH}:$ Masadir Inc.

Heung, V. C. S. (2003). Internet usage by international travellers: reasons and barriers. International Journal of Contemporary Hospitality Management, 15(7), 370-378.

Hoffman, D. L., \& Novak, T. P. (1996). Marketing in hypermedia computer-mediated environments: conceptual foundations. Journal of Marketing, 60(3), 50-68.

Homans, G. C., (1961). Social behavior: its elementary forms. London, LO: Routlege and Kegan Paul. 
Koch, J. V., \& Cebula, R. J. (2002). Contemporary Economic Policy, 20(1), 25-37.

Jerath, K., Netessine, S., \& Veeraraghavan, S. K. (2010) Revenue Management with Strategic Customers: Last-Minute Selling and Opaque Selling. Management science, 56(3), 430-448.

Kitchathorn, P. (2009) Factor influencing customer repurchase intention: an investigation of switching barriers that influence the relationship between satisfaction and repurchase intention in the low-cost airlines industry in Thailand. Australia, AU: University of South Australia.

Kotler, P., \& Armstrong, G. (2010). Principles of Marketing, (13 ${ }^{\text {th }}$ ed.). New Jersey, NJ: Pearson Education.

Koo, B., Mantin, B., \& O’Connor, P. (2009). Online distribution of airline tickets: should airlines adopt a single or multi-channel approach? Journal of Tourism Management, 32(2), 69-74.

Leelayouthayotin, L. (2004). Factors influencing online purchase intention: The case of health food consumers in Thailand. Submitted in partial fulfillment of the degree of Doctor in Business Administration. Queensland, QE: Faculty of Business University of Southern Queensland.

Lim, H., \& Dubinsky, J. A. (2004). Consumer's perception of e-shopping characteristics: an expectancy-value approach. Journal of Service Marketing, 18(7), 500-513.

Lee, G. G., \& Lin, H. F. (2005). Customer perceptions of e- service quality in online shopping. International Journal Retail \& Distribution Management. 33(2), 161-176.

Madu, C. N., \& Madu, A. A. (2002). Dimensions of e-quality. International Journal of Quality \& Reliability Management, 19(3), 246-258.

Malhotra, N. K., \& Birks, D. F. (2000). Marketing Research: an applied approach. England, EN: Pearson Education Limited.

Melão, N. (2009). E-Business Processes and E-Business Process Modelling: A State-of-theArt Overview. International Journal of Services, Technology and Management, 11(3), 293-322.

Morrisson, O. (2005). Influence modératrice de l'équité externe sur la relation disconfirmation des attentes - satisfaction à l'égard des actions de service recovery. Lyon,

LY : Université Lyon 3.

Nasse, T. B. (2016). L'équité interne dans la gestion de la relation client: une étude comparative quantitative de trois entreprises privées du Burkina Faso. Université Aube Nouvelle, Journal Ouest-Africain des Sciences de Gestion, 1(1), 1-16.

Nasse, T. B. (2019). Internal equity and customer relationship management in developing countries: A quantitative and a comparative study of three private companies in Burkina Faso. African Journal of Business Management, 13(1), 37-47. Https://doi.org/10.5897/AJBM2018.8663.

Nasse, T. B., \& Sawadogo, Y. M. (2019). Internal equity and customer relationship management in subsistence markets: a comparative and a qualitative study of three private companies in Burkina Faso. International Journal of Management \& 
Entrepreneurship Research, $\quad$ 4(1), Https://www.fepbl.com/index.php/ijmer/article/view/5.

Öörni, A. (2003). Consumer search in electronic markets: an experimental analysis of travel services. European Journal of Information Systems 12(1), 30-40.

Parasuraman, A., Zeithaml, V. A., \& Berry, L. L. (1988). SERVQUAL: a multiple-item scale for measuring consumer perceptions of service quality. Journal of Retailing, 64(1), $12-40$.

Perreti, J. M. (2004). Les clés de l'équité : enjeu managérial. Paris, PA : Éditions d'Organisation.

Ranaweera, C., \& Prabhu, J. (2003).The influence of satisfaction, trust and switching barriers on customer retention in a continuous purchasing setting. International Journal of Service Industry Management, 14(4), 374-395.

Stigler, G. J. (1961). The Economics of Information. Journal of Political Economy, 69(3), 213-225.

Teo, T.S.H. (2001). Demographics and Motivation Variables associated with Internet usage activities. Internet Research: Electronic Networking Applications and Policy, 11(2), 125-137.

Van Laethem, N., \& Body, L. (2008). Le plan marketing (2 ${ }^{\text {ème }}$ éd.). Paris, PA : Dunod.

Zwass, V. (1996). Electronic Commerce: Structures and Issues. International Journal of Electronic Commerce, 1(1), 3-23.

Wolfinbarger, M., \& Gilly, M. (2001). Shopping online for freedom, control and fun. California Management Review, 43(2), 34-55.

Wolfinbarger, M., \& Gilly, M. (2000). A comparison of consumer experiences with online and offline shopping. Consumption, Markets and Culture, 4(2), 187-205.

Yang, Z., \& Jun, M. (2002). Consumer perceptions of e-service quality: from internet purchaser and non-purchaser perspectives. Journal of Business Strategies, 1(1),1941.

$\mathrm{Yu}$, S. (2008). Price perception of online airline ticket shoppers. Journal of Air Transport Management, 14(2), 66-69.

Zeithaml, V. A., Parasuraman A., \& Malhotra, A. (2000). A conceptual framework for understanding e-service quality: implications for future research and managerial practice. Cambridge, CA: England.

Zeithaml, A. V., Lemon, K. N., \& Rust, R. T. (2004). Return on marketing: using customer equity to focus marketing strategy. Journal of Marketing, 68(1), 109-127.

\section{Acknowledgements}

The authors are thankful to the following Universities: Amity University, University of Ouagadougou, University of Ouaga 2, New Dawn University, University for Development Studies, and Saint Thomas D'Aquin University, and the Polytechnic College of Youth. The authors are also grateful and thankful to the German DAAD program, to Fair East Publishers, and to the respondents who answered the questions and to the airline company leaders that contributed to the present research.

\section{Conflict of Interest Statement}

No conflict of interest has been declared by the authors. 